\title{
Effect of olive oil production steps on the physicochemical properties and phenolic compounds of olive oil
}

Zeytinyağı üretim aşamalarının zeytinyağının fizikokimyasal özellikleri ve fenolik bileşenleri üzerine etkisi

\author{
Nurhan USLU (D)
}

Selçuk University, Faculty of Agriculture, Department of Food Engineering, Konya.

MAKALE BILGISI / ARTICLE INFO

Makale tarihçesi / Article history:

DOI: $10.37908 /$ mkutbd.847769

Geliş tarihi /Received:05.01.2021

Kabul tarihi/Accepted:19.02.2021

Keywords: Phenolic compounds, physicochemical properties, malaxation, fatty acids, olive oil.

Corresponding author: Nurhan USLU
$\square:$ nurhanuslu@selcuk.edu.tr

\author{
ÖZET / A BSTRACT
}

Atıf / Citation: Uslu N (2021) Effect of olive oil production steps on the physicochemical properties and phenolic compounds of olive oil. MKU. Tar. Bil. Derg. 26(2) : 249-256. DOI: $10.37908 /$ mkutbd.847769

\section{INTRODUCTION}

Olive (Olea europaea L.) oil is a significant part of the Mediterranean diet (Dag et al., 2011). Virgin olive oil draws the attention because of its fatty acid composition characterized by the high amount of monounsaturated fatty acids, and its phenolic compounds that exhibit great antioxidant activity (Velasco and Dobarganes, 2002). The physical processes, such as crushing, malaxation and separation in comparison to chemical techniques provide the better nutritional value and organoleptic properties to virgin olive oil (Boselli et al., 2009; Taticchi et al., 2013). Firstly, the crushing enables to extraction of oil from the intracellular oil vacuoles using the several crushing techniques, such as the stone mill, blade crusher, or hammer mill (Polari et al., 2018). The malaxation is a significant process by mixing the olive paste which breaks of the emulsion, enlarges the diameter of oil droplets, makes the separation process easier (Yorulmaz et al., 2017). According to the previous 
studies, an important difference is not observed in the chemical properties of olive oils such as free fatty acid and peroxide values by using method of crushing. In contrast to this, total phenolic contents of oils show the change among the used crushing devices such as metallic crushers or stone mill (Di Giovacchino et al., 2002). Endogenous enzymes of fruit, such as $\beta$-glucosidases and esterases, are activated with the malaxation process, causing hydrolysis of some phenolic compounds, especially oleuropein and ligstroside, thereby forming secoiridoid derivatives (Clodoveo, 2012). When the separation methods were compared, the lowest bioactive components were detected in virgin olive oils extracted by 3-phase centrifuges. The addition of water caused by the decrease in the amount of bioactive components. Because some of the phenolic compounds dissolve in water added in 3-phase centrifuges and bioactive compound amounts reduce (Di Giovacchino et al., 1994; Welsh and Williams, 1989). During the extraction processes, the volatile and phenolic compounds are affected due to the enzymatic reactions which lead to oxidation of phenolic compounds and consequently cause the reduction in phenolic compound contents in virgin olive oil (Clodoveo et al., 2014). The amounts of bioactive compounds are depend on not only extraction processes but also variety, harvest year, location, fruit ripeness, and storage conditions (Seçmeler and Güçlü Üstündağ, 2017). The oxidative stability of virgin olive oil is mainly due to presence of phenolic compounds, especially containing catechol moieties, such as oleuropein aglycone (3,4-DHPEA-EA) and oleacein (3,4-DHPEA-EDA) (Baldioli et al., 1996; Romani et al., 2007). However, it was informed that simple phenols such as hydroxytyrosol provide lower oxidative resistance (Paiva-Martins et al., 2006). Consequently, the oil extraction process from olive causes several chemical and enzymatic differences, accordingly, the extraction steps play a vital role for quality and shelf life of olive oil. In the literature, different results were informed according to the malaxation conditions (especially temperature and time) or crushing devices. However, there is a lack of publications about the olive oil obtained from industrial olive oil mill. The principal purpose of this study was to investigate the bioactive compounds and physicochemical properties of olive oils extracted from olive, olive paste after crushing, malaxation and decantation which were taken oil factory during process.

\section{MATERIALS and METHODS}

\section{Material}

Samples, which are olive, olive paste after crusher and malaxator, and olive oil after decanter, were separately obtained from a facility in Mersin (Mut) province of Turkey. The samples belonged to olive fruits of two different varieties (Ayvalık and Gemlik). The using crusher was hammer mill. The malaxation time and temperature were $20 \mathrm{~min}$ and $35^{\circ} \mathrm{C}$, respectively. The virgin olive oil was extracted by 2 -phase centrifuge. The samples were brought to the laboratory in glass jar.

\section{Methods}

\section{Oil content}

Oil contents of samples (olive, olive paste after crusher and malaxator) were determined according to AOAC (1990) method. Total oil content of samples was extracted with petroleum benzine in Soxhlet Apparatus for $5 \mathrm{~h}$, and the solvent was removed with a rotary vacuum evaporator at $50 \circ \mathrm{C}$.

\section{Color analysis}

Color values of oil samples were measured with Minolta Chroma meter CR 400 (Konica Minolta, Inc. Osaka, Japan) according to the International Commission on Ilumination $L^{*}, a^{*}, b^{*}$ scale (Rizzo et al., 2014).

\section{Analyses of free fatty acid and peroxide values}

Free fatty acids, expressed as free oleic acid percentage, and peroxide values, expressed as milliequivalents of active oxygen per kilogram oil, (meq $\mathrm{O}_{2} \mathrm{~kg}^{-1}$ ) were found according to AOCS (1989) Official Method Ca 5a-40 and Cd 8-53, respectively.

\section{Sample extraction}

Olive oils were extracted according to Konuskan and Mungan (2016). The oils $(2 \mathrm{~mL})$ were added to $1 \mathrm{~mL}$ of hexan and $4 \mathrm{~mL}$ of methanol:water mixture $(60 / 40, v / \mathrm{v})$. The mixture was vortexed for $2 \mathrm{~min}$, followed by centrifugation at $6000 \mathrm{rpm}$ for $5 \mathrm{~min}$. These steps were repeated twice and the supernatants were collected. The extract was filtered with $0.45 \mu \mathrm{m}$ PTFE filter before analysis.

\section{Total phenolic content}

The total phenolic contents of extracts were determined using the Folin-Ciocalteu (FC) reagent according to Yoo et al. (2004). FC (1 mL) was added to the samples and mixed for $5 \mathrm{~min}$. Following the addition of $10 \mathrm{~mL}$ of $\mathrm{Na}_{2} \mathrm{CO}_{3}(7.5 \%)$, the solution in the tubes was mixed again, and the final volume was adjusted to $25 \mathrm{~mL}$ with deionized water. At the end of $1 \mathrm{~h}$, the total phenol content was determined at a wavelength of $750 \mathrm{~nm}$ in a 
spectrophotometer (Shimadzu, Japan) with a calibration curve made using gallic acid $\left(0-200 \mathrm{mg} \mathrm{mL}^{-1}\right)$ as the standard. The results are given as $\mathrm{mg}$ gallic acid equivalent (GAE) $\mathrm{L}^{-1}$ of fresh weight.

\section{Antioxidant activity}

The free radical scavenging activities of extracts were determined using DPPH (1,1-diphenyl-2-picrylhydrazyl) according to study of Lee et al. (1998). The extract was mixed with $2 \mathrm{~mL}$ methanolic solution of DPPH. After shaking vigorously, it was stored at room temperature for $30 \mathrm{~min}$. The absorbance was recorded at $517 \mathrm{~nm}$ by using a spectrophotometer (Shimadzu, Japan).

\section{Determination of phenolic compounds}

Phenolic compounds of extracts were determined using a Shimadzu-HPLC equipped with a PDA detector and an Inertsil ODS-3 (5 $\mu \mathrm{m} ; 4.6 \times 250 \mathrm{~mm})$ column. Gradient elution was performed for separation, and a mixture of $0.05 \%$ acetic acid in water (A) and acetonitrile (B) as the mobile phases were used. The gradient program was as follows: $0-0.10 \mathrm{~min} 8 \% \mathrm{~B} ; 0.10-2 \mathrm{~min} 10 \% \mathrm{~B} ; 2-27 \mathrm{~min}$ $30 \% \mathrm{~B} ; 27-37 \mathrm{~min} 56 \% \mathrm{~B} ; 37-45 \mathrm{~min} 8 \% \mathrm{~B}$. The flow rate

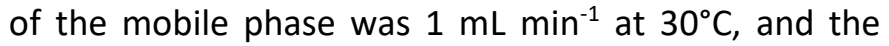
injection volume was $20 \mu \mathrm{L}$. The peaks were recorded at $280 \mathrm{~nm}$ using a PDA detector. The total running time per sample was $60 \mathrm{~min}$.

\section{Fatty acid composition}

Olive oils were esterificated according to ISO-5509 (1978) method with some modifications. Fatty acid methyl esters of oil samples were analyzed gas chromatography (Shimadzu GC-2010) equipped with flame-ionization detector (FID) and capillary column (Tecnocroma TR-CN100, $60 \mathrm{~m} \times 0.25 \mathrm{~mm}$, film thickness: $0.20 \mu \mathrm{m})$. The temperature of injection block and dedector was $260^{\circ} \mathrm{C}$. Mobile phase was nitrogen with $1.51 \mathrm{~mL} \mathrm{~min}^{-1}$ flow rate. Total flow and split rates were $80 \mathrm{~mL} \mathrm{~min}^{-1}$ and $1 / 40$, respectively. Column temperature was programmed $120^{\circ} \mathrm{C}$ for 5 minutes and increased $240^{\circ} \mathrm{C}$ at $4 \stackrel{\circ}{ } \mathrm{C} \mathrm{min}^{-1}$ and held 25 minutes at $240 \circ \mathrm{C}$. A standard fatty acid methyl ester mixture (Sigma Chemical Co.) was used to determine sample peaks. Commercial mixtures of fatty acid methyl esters were used as reference data for the relative retention times.

\section{Statistical analysis}

Statistical analysis of the results was performed using Minitab-16 statistical program. The means of significant variation sources were compared to Tukey Test. The significance level is given as $p<0.05$ unless otherwise stated. The analyzes were repeated 3 times $(n=3)$.

\section{RESULTS and DISCUSSION}

The physicochemical properties of samples are presented in Table 1 . The highest oil content $(56.80 \%$, $\mathrm{dw}$ ) was determined in olive paste after malaxation process. The malaxation is an effective process to increase the oil yield of olives due to break of the emulsion and help oil droplets come together. The $L^{*}, a^{*}$ and $b^{*}$ values of olive oils varied between 73.82 and $82.04,-3.71$ and $-12.60,14.22$ and 45.78 , respectively. The highest $L^{*}$ and $a^{*}$, and the lowest $b^{*}$ values were determined in olive oil obtained after decantation. Extracting the oils from olives and olive pastes after crusher and malaxation using the soxhlet method significantly changed the $L^{*}, a^{*}$ and $b^{*}$ values of the oils. Soxhlet extraction method in comparison to continue extraction system caused less brightness, greenish and yellowish oil. The use of solvent in the extraction was probably increase the transition of color components, especially chlorophyll and carotenoids, to oil. According to the study of Criado et al. (2007), the $L^{*}, a^{*}$ and $b^{*}$ values of olive oils belonged to Arbequina and Farga varieties were determined as 68.5-93.3 and 78.1-95.3; 3.4- (-) 9.9 and -2.9- (-) 5.4; 40.2-114.6 and 26.5-116.7, respectively. The $L^{*}, a^{*}$ and $b^{*}$ values of the Lechin olive oils varied between 94.2 and $97.5,-7.0$ and (-) 9.8, 21.9 and 34.3, respectively (Minguez-Mosquera et al., 1991). Romero et al. (2003) reported that color values of olive oils were measured between 76.4 and 89.3 for $L^{*}$ values; -0.61 and -3.53 for $a^{*}$ values; 90.0 and 108.8 for $b^{*}$ values.

The free fatty acid contents and peroxide values of olive oils ranged from $1.68 \%$ to $2.46 \%$; from 1.5 meq $\mathrm{O}_{2} \mathrm{~kg}^{-1}$ to 15.5 meq $\mathrm{O}_{2} \mathrm{~kg}^{-1}$, respectively. The extraction steps caused the increase in free acidity of oils and the maximum acidity was observed after malaxation process because of increasing lipase activity. This was in agreement with data reported from other studies (Yorulmaz et al., 2017; Jimenez et al., 1995; Kalua et al., 2006). The lowest peroxide value was determined after decanter, with the range of 1.5 meq $\mathrm{O}_{2} \mathrm{~kg}^{-1}$. It can be seen that the peroxide value reduced with extraction steps progressed because peroxides are not a stable product. In a study of Yorulmaz et al. (2017), free fatty acid and peroxide values of olive oil were founds as $0.63 \%$ and $6.22 \mathrm{mg} \mathrm{O}_{2} \mathrm{~kg}^{-1}$ oil after $20 \mathrm{~min}$ of malaxation process, respectively. Polari et al. (2018) informed that malaxation time affected both free fatty acid and peroxide values. When the malaxation time was increased from 30 to $75 \mathrm{~min}$, the free fatty acid and peroxide values shown an increase from $0.19 \%$ to $0.26 \%$; 
from 6.0 meq $\mathrm{O}_{2} \mathrm{~kg}^{-1}$ to 7.4 meq $\mathrm{O}_{2} \mathrm{~kg}^{-1}$, respectively. According to the study of Stefanoudaki et al. (2011), acidity and peroxide values of olive oil belonged to Coratina variety, applied 20 min of malaxation, and used 2-phases decanter were found as $0.29 \%$ and 6.24 meq $\mathrm{O}_{2}$ $\mathrm{kg}^{-1}$ oil, respectively.

Table 1. The physicochemical properties of olive oils belonging to olive and olive paste obtained after crushing, malaxation and decanter

\begin{tabular}{|c|c|c|c|c|c|c|c|c|}
\hline \multirow{2}{*}{$\begin{array}{l}\text { Process steps } \\
\text { Olive }\end{array}$} & Oil content $(\%, d w)$ & \multicolumn{2}{|r|}{$L^{*}$} & \multicolumn{2}{|r|}{$a^{*}$} & \multicolumn{3}{|c|}{$b^{*}$} \\
\hline & $41.80 \pm 0.37^{b}$ & 77.12 & $\pm 2.03^{a}$ & 1.68 & $\pm 0.07^{d}$ & 12.5 & \pm & $0.71^{b}$ \\
\hline After crusher & $36.15 \pm 1.35^{b}$ & 74.57 & $\pm 3.51^{a}$ & 2.24 & $\pm 0.02^{b}$ & 15.5 & \pm & $0.60^{\mathrm{a}}$ \\
\hline After malaxation & $56.80 \pm 1.60^{a}$ & 73.82 & $\pm 2.56^{a}$ & 2.46 & $\pm 0.31^{a}$ & 8.5 & \pm & $0.52^{c}$ \\
\hline \multirow[t]{2}{*}{ After decanter } & - & 82.04 & $\pm 1.99^{a}$ & 2.06 & $\pm 0.06^{c}$ & 1.5 & \pm & $0.54^{d}$ \\
\hline & Free acidity (\%) & \multicolumn{2}{|c|}{$\begin{array}{l}\text { Peroxide value } \\
\left.\text { (meq } \mathrm{O}_{2} \mathrm{~kg}-1\right)\end{array}$} & \multicolumn{2}{|c|}{$\begin{array}{l}\text { Total phenolic content } \\
\text { (mg L-1) }\end{array}$} & \multicolumn{3}{|c|}{$\begin{array}{c}\text { Antioxidant activity } \\
(\%)\end{array}$} \\
\hline Olive & $1.68 \pm 0.07^{d}$ & 12.5 & $\pm 0.71^{b}$ & 450.60 & $\pm 0.89^{a}$ & 50.14 & \pm & $0.82^{a}$ \\
\hline After crusher & $2.24 \pm 0.02^{b}$ & 15.5 & $\pm 0.60^{a}$ & 193.80 & $\pm 0.36^{b c}$ & 31.26 & \pm & $0.16^{c}$ \\
\hline After malaxation & $2.46 \pm 0.31^{a}$ & 8.5 & $\pm 0.52^{c}$ & 160.70 & $\pm 0.21^{c}$ & 31.55 & \pm & $0.50^{c}$ \\
\hline After decanter & $2.06 \pm 0.06^{c}$ & 1.5 & $\pm 0.54^{d}$ & 267.20 & $\pm 0.66^{b}$ & 41.54 & \pm & $0.67^{b}$ \\
\hline
\end{tabular}

Different superscript letters in the same column indicate significant difference between mean values at $p<0.05$.

For Koroneiki variety, in the same conditions, the acidity and peroxide values of olive oil were determined as $0.48 \%$ and 7.96 meq $\mathrm{O}_{2} \mathrm{~kg}^{-1}$ oil, respectively. In another study, crushing methods such as metallic crusher+stones, metallic crusher and stone mill did not significantly affect the free fatty acid $(0.14-0.17 \%$ for Ogliarola di Bitonto+Leccino varieties; $0.16-0.17 \%$ for Peranzana+Leccino varieties), and peroxide (5.9-6.2 meq $\mathrm{O}_{2} \mathrm{~kg}^{-1}$ for Ogliarola di Bitonto+Leccino varieties; 4.9-5.7 meq $\mathrm{O}_{2} \mathrm{~kg}^{-1}$ for Peranzana+Leccino varieties) values of olive oils (Preziuso et al., 2010). Kula et al. (2018) observed that free fatty acid and peroxide values of olive oil extracted from crushed paste were established as $0.71 \%$ and 5.30 meq $\mathrm{O}_{2} \mathrm{~kg}^{-1}$ oil while these values were determined as $0.70 \%$ and 6.42 meq $\mathrm{O}_{2} \mathrm{~kg}^{-1}$ oil for olive oil obtained from crushed+malaxed paste, respectively. As indicated by Caponio et al. (2014), free fatty acid and peroxide values of olive oils were determined as $0.28 \%$ and $2.65 \mathrm{meq}_{2} \mathrm{~kg}^{-1}$, respectively.

Total phenolic contents of olive oils ranged from 160.70 mg GAE L ${ }^{-1}$ (olive oil extracted after malaxation) to 450 $\mathrm{mg}$ GAE $\mathrm{L}^{-1}$ (oilve oil extracted from olives). The malaxation process at $35^{\circ} \mathrm{C}$ decreased the total phenolic content of oil, followed by crushing process. Similarly, the antioxidant activity was negatively affected from malaxation and crushing steps. The antioxidant activity decreased from $50.14 \%$ to $31.26 \%$ after crushing and to $31.55 \%$ after malaxation. This reduction originated from the activation of polyphenoloxidase and peroxidase enzymes which oxidised phenolic components (Yorulmaz et al., 2012). Contrary to present study, Kula et al. (2018) reported that total phenolic contents of olive oils increased from $150.70 \mathrm{mg} \mathrm{kg}^{-1}$ to $250.60 \mathrm{mg} \mathrm{kg}$ ${ }^{1}$ with malaxation process at $30^{\circ} \mathrm{C}$. Total phenolic content of olive oil belonged to Ayvalık variety was $191.23 \mathrm{mg} \mathrm{kg}$ ${ }^{1}$ when olive paste was malaxation for $20 \mathrm{~min}$ (Yorulmaz et al., 2017). Stefanoudaki et al. (2011) observed that total phenolic contents of olive oils were determined as $187.85 \mathrm{ppm}$ for Coratina variety and $153.57 \mathrm{ppm}$ for Koroneiki variety when kneaded for $20 \mathrm{~min}$ and extracted by 2-phase decanter. Total phenolic content of olive oil extracted from Ogliarola di Bitonto+Leccino varieties and used metallic crusher was found as $86 \mathrm{mg}$ $\mathrm{L}^{-1}$ while it was determined as $212 \mathrm{mg} \mathrm{L}^{-1}$ for olive oil of Peranzana+Leccino varieties (Preziuso et al., 2010). Caponio et al. (2014) informed that total phenolic contents of olive oils extracted by 2-phase decanter ranged from $674 \mathrm{mg} \mathrm{kg}^{-1}$ to $743 \mathrm{mg} \mathrm{kg}^{-1}$, while total phenolic amounts of oils obtained from 3-phase decanter varied from $553 \mathrm{mg} \mathrm{kg}^{-1}$ to $602 \mathrm{mg} \mathrm{kg}^{-1}$. The antioxidant activities were found between $52.18 \%$ and $60.52 \%$ in olive oils extracted by 2 -phases system; between $50.24 \%$ and $52.60 \%$ in oils obtained by $3-$ phases system.

The phenolic compounds of olive oils are illustrated in Fig. 1. The major phenolic compound of olive oils was found as verbascoside (19.09-20.89 $\left.\mathrm{mg} \mathrm{L}^{-1}\right)$, followed by rutin (13.60-15.24 $\mathrm{mg} \mathrm{L}^{-1}$ ) and luteolin-7-glucoside (12.80-13.95 $\left.\mathrm{mg} \mathrm{L}^{-1}\right)$ in descending order. In addition, the hydroxytyrosol, tyrosol and oleuropein contents of olive oils were equal to 7.75-9.29 $\mathrm{mg} \mathrm{L}^{-1}, 6.77-9.06 \mathrm{mg} \mathrm{L}^{-1}$, 9.63-10.87 $\mathrm{mg} \mathrm{L}^{-1}$, respectively. 


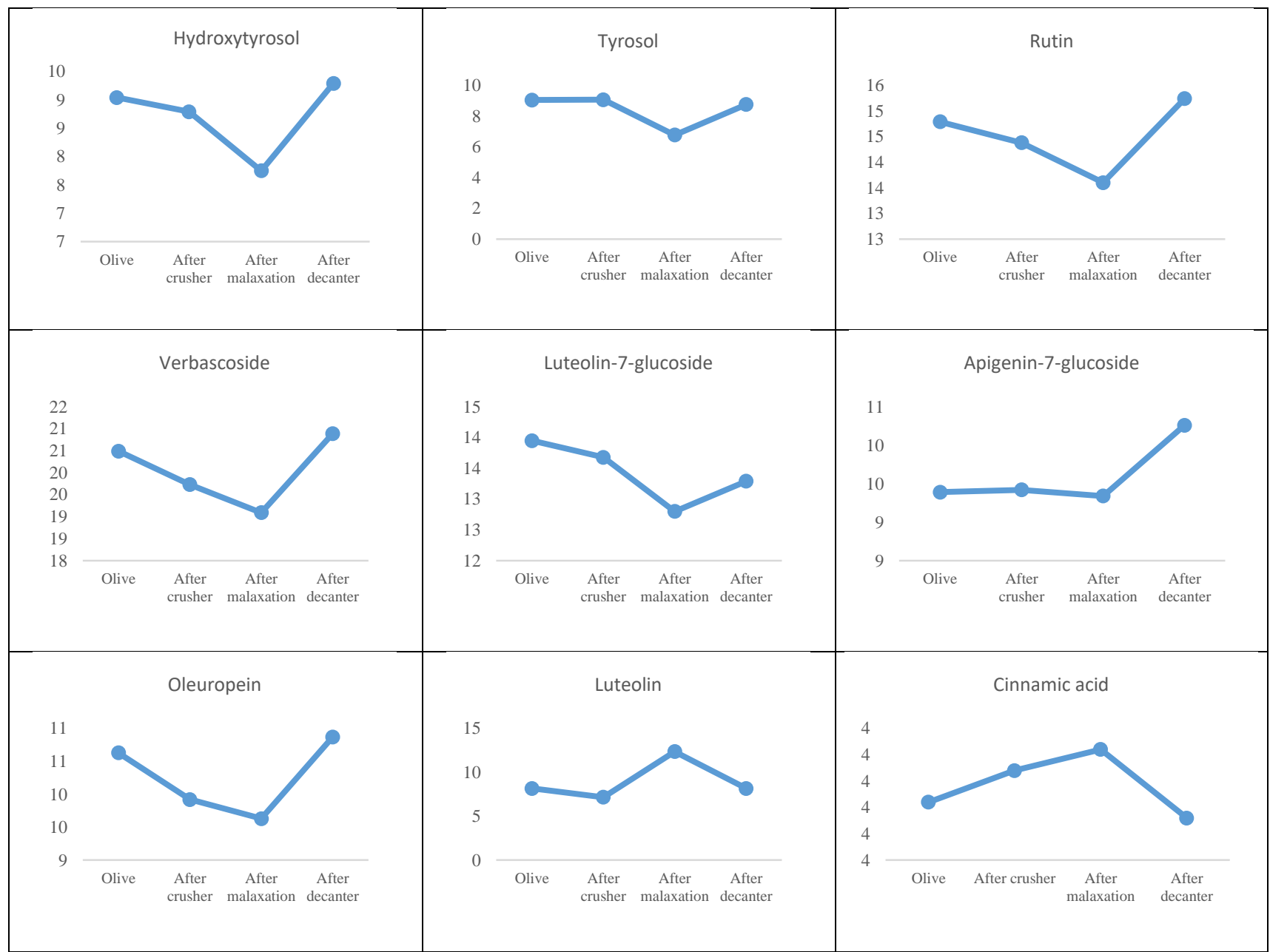

Figure 1. Phenolic compounds of olive oils belonging to olive and olive paste obtained after crushing, malaxation and decanter $\left(\mathrm{mg} \mathrm{L}^{-1}\right)$

The phenolic compounds, except luteolin, were not significantly affected from extraction processes. The olive oil obtained from olive paste after malaxation contained the highest amount of luteolin $\left(12.36 \mathrm{mg} \mathrm{L}^{-1}\right)$. Preziuso et al. (2010) reported that hydroxytyrosol and tyrosol amounts of olive oils extracted from olive pastes prepared using metallic crusher were found as $1.8 \mathrm{mg} \mathrm{kg-}$ 1 and $12.7 \mathrm{mg} \mathrm{kg}^{-1}$ for Ogliarola di Bitonto+Leccino; 3.4 $\mathrm{mg} \mathrm{kg}$ and $6.7 \mathrm{mg} \mathrm{kg}^{-1}$ for Peranzana+Leccino, respectively. The hydroxytyrosol and tyrosol contents of the oils extracted from Cornicabra olives were found as 2.14 and $2.80 \mathrm{mg} \mathrm{kg}^{-1} ; 1.62$ and $2.25 \mathrm{mg} \mathrm{kg}^{-1}$, respectively (Gomez-Rico et al., 2006). The tyrosol contents of olive oils belonged to different varieties were found between $3.5 \mathrm{mg} \mathrm{kg}^{-1}$ (Carpinetana variety) and $6.3 \mathrm{mg} \mathrm{kg}^{-1}$ (Intosso variety), while the amount of hydroxytyrosol was determined between $2.2 \mathrm{mg} \mathrm{kg}^{-1}$ (Rustica variety) and $7.1 \mathrm{mg} \mathrm{kg}^{-1}$ (Intosso variety) (Ambra et al., 2017). Caponio et al. (2001) informed that the hydroxytyrosol, tyrosol, oleuropein and cinnamic acid content of the oils extracted from green-yellow olives were found as 1.20,
2.95, 0.64 and $0.26 \mathrm{mg} \mathrm{kg}^{-1}$ (Carotina variety); 2.11, 6.47, 5.16 and $0.16 \mathrm{mg} \mathrm{kg}^{-1}$ (Ogliarola salentina variety) while these phenolics of the oils extracted from purple-black olives were determined as $1.92,3.65,0.23$ and $0.25 \mathrm{mg}$ $\mathrm{kg}^{-1}$ (Carotina variety); 2.77, 6.97, 1.74 and $0.10 \mathrm{mg} \mathrm{kg}^{-1}$ (Ogliarola salentina variety), respectively. In another study, hydroxytyrosol, tyrosol, and luteolin contents of olive oils varied between $0.09-0.80 \mathrm{mg} \mathrm{kg}^{-1}, 0.68-1.13 \mathrm{mg}$ $\mathrm{kg}^{-1}, 0.27-2.28 \mathrm{mg} \mathrm{kg}^{-1}$ for Ayvalık variety; $0.16-0.63 \mathrm{mg}$ $\mathrm{kg}^{-1}, 0.53-1.57 \mathrm{mg} \mathrm{kg}^{-1}, 0.28-1.74 \mathrm{mg} \mathrm{kg}^{-1}$ for Gemlik variety, respectively (Dağdelen et al., 2013).

Fatty acid compositions of olive oils are demonstrated in Table 2. The lowest oleic acid (68.58\%); the highest linoleic $(11.57 \%)$ and palmitic $(14.66 \%)$ acid contents were observed in olive oil extracted after malaxation. Applying processes such as crushing with metallic crusher and malaxation for $\mathbf{2 0}$ min decreased oleic acid, and increase the linoleic acid amounts. Accordingly, the extraction steps had the significant effect on fatty acid composition, especially major fatty acids $(p<0.05)$. 
Table 2. Fatty acid compositions of olive oils belonging to olive and olive paste obtained after crushing, malaxation and decanter (\%)

\begin{tabular}{|c|c|c|c|c|c|c|c|c|c|}
\hline Fatty acids (\%) & \multicolumn{2}{|c|}{ Olive } & \multicolumn{2}{|c|}{ After crusher } & \multicolumn{2}{|c|}{ After malaxation } & \multicolumn{3}{|c|}{ After decanter } \\
\hline Palmitic & $13.25 \pm$ & $0.29^{*}$ & 13.19 & \pm 0.10 & $14.66 \pm$ & \pm 0.56 & 13.96 & \pm & 0.07 \\
\hline Stearic & $2.17 \pm$ & $0.09^{b}$ & 2.32 & $\pm 0.01^{\mathrm{ab}}$ & $2.31 \pm$ & $\pm 0.04^{\mathrm{ab}}$ & 2.50 & \pm & $0.00^{\mathrm{a}}$ \\
\hline Oleic & $71.31 \pm$ & $0.16^{a}$ & 70.84 & $\pm 0.08^{a}$ & $68.58 \pm$ & $\pm 0.38^{b}$ & 71.06 & \pm & $0.22^{\mathrm{a}}$ \\
\hline Linoleic & $9.85 \pm$ & $0.02^{c}$ & 10.80 & $\pm 0.01^{b}$ & $11.57 \pm$ & $\pm 0.11^{\mathrm{a}}$ & 8.77 & \pm & $0.04^{d}$ \\
\hline Arachidic & $0.39 \pm$ & 0.03 & 0.39 & \pm 0.00 & $0.36 \pm$ & \pm 0.02 & 0.34 & \pm & 0.00 \\
\hline Linolenic & $0.40 \pm$ & $0.00^{\mathrm{ab}}$ & 0.38 & $\pm 0.00^{c}$ & $0.41 \pm$ & $\pm 0.00^{\mathrm{a}}$ & 0.39 & \pm & $0.00^{b c}$ \\
\hline Behenic & $0.12 \pm$ & 0.07 & 0.12 & \pm 0.00 & $0.10 \pm$ & \pm 0.01 & 0.09 & \pm & 0.00 \\
\hline Arachidonic & $0.30 \pm$ & $0.02^{b}$ & 0.24 & $\pm 0.01^{b}$ & $0.26 \pm$ & $\pm 0.02^{b}$ & 0.75 & \pm & $0.00^{\mathrm{a}}$ \\
\hline
\end{tabular}

*Mean values are statistically insignificant ( $p>0.05$ ). Different superscript letters in the same line indicate significant difference between mean values at $p<0.05$.

Kelebek et al. (2015) informed that the oleic acid content (75.85\%) of Gemlik olive oil was higher than the oil of Ayvalık variety (68.95\%), while the highest and lowest palmitic acid contents were found as $14.51 \%$ in Ayvalık olive oil and $11.42 \%$ in Gemlik olive oil, respectively. Kula et al. (2018) observed an increase in the linoleic acid content (from $9.9 \%$ to $16.4 \%$ ) and a decrease in the palmitic and oleic acid amounts (from $12.6 \%$ to $11.2 \%$ and from $72.7 \%$ to $67.9 \%$, respectively) of olive oil when the malaxation process applied at $30^{\circ} \mathrm{C}$. After malaxation process for $20 \mathrm{~min}$, the oleic, linoleic and palmitic acid contents of olive oil were determined as $70.35 \%, 11.98 \%$ and $13.64 \%$, respectively (Yorulmaz et al., 2017). In some studies, fatty acid composition did not show differences with malaxation (Inarejos-Garcia et al., 2009; Jimenez et al., 2014). On the other hand, Youssef et al. (2013) reported that malaxation process about $15-30 \mathrm{~min}$ caused the highest oleic acid and the lowest palmitic acid contents.

\section{ÖZET}

Amaç: Bu çalışmada, endüstriyel ölçekli sürekli ekstraksiyon işlemi aşamalarının (kırma, malaksasyon ve dekantasyon) zeytinyağının fizikokimyasal (yağ içerikleri, $L^{*}, a^{*}, b^{*}$, serbest asitlik, peroksit değerleri) ve biyoaktif özellikleri (toplam fenol içeriği, antioksidan aktivitesi ve fenolik bileşenleri) üzerine etkisinin araştırılması amaçlanmıştır.

Yöntemler ve Bulgular: Zeytinyağı işletmesinden temin edilen zeytin, kırma ve malaksasyon işlemleri sonrası zeytin hamuru ve dekantör sonrası zeytinyağı örnekleri analiz için kullanılmıştır. En yüksek yağ (\%56.80) ve en düşük toplam fenol $\left(160.70 \mathrm{mg} \mathrm{L}^{-1}\right)$ içerikleri $35^{\circ} \mathrm{C}^{\prime}$ de 20 dakika süreyle malaksasyon işleminden sonra belirlenmiştir. Dekantörden sonra zeytinyağının serbest yağ asidi değeri \%1.68'den \%2.46'ya yükselirken, yağın peroksit değeri 12.5 meq $\mathrm{O}_{2} \mathrm{~kg}^{-1}$ dan 1.5 meq $\mathrm{O}_{2} \mathrm{~kg}^{-1} \mathrm{a}$ düşüş göstermiştir. Zeytinyağlarının $L^{*}, a^{*}$ ve $b^{*}$ değerleri sırasıyla 73.82 ve $82.04,-12.60$ ve $-3.71,14.22$ ve 45.78 arasında belirlenmiştir. Ayrıca, fenolik bileşiklerin endüstriyel yağ ekstraksiyon işleminden önemli ölçüde etkilenmediği tespit edilmiştir ( $p>0.05)$. En düşük oleik asit (\%68.58) ve en yüksek linoleik asit (\%11.57) ve palmitik asit (\%14.66) konsantrasyonları malakse edilmiş zeytin hamurundan elde edilen zeytinyağında gözlenmiştir.

Genel Yorum: Örneklerin yağ verimi, yağ asidi kompozisyonu ve toplam fenol içeriği sonuçları, malaksasyon işlemi sonrası önemli farklılıklar sergilemiştir.

Çalışmanın Önemi ve Etkisi: Malaksasyon işleminin, zeytinyağı kalitesini önemli ölçüde etkileyen ekstraksiyon aşaması olduğu tespit edilmiştir.

Anahtar kelimeler: Fenolik bileşen, fizikokimyasal özellikler, malaksasyon, yağ asitleri, zeytinyağı.

\section{CONFLICT OF INTEREST}

The authors declare no conflict of interest for this study.

\section{REFERENCES}

Ambra R, Natella F, Lucchetti S, Forte V, Pastore G (2017) $\alpha$-Tocopherol, $\beta$-carotene, lutein, squalene and secoiridoids in seven monocultivar Italian extra-virgin olive oils. Int. J. Food Sci. Nutr. 68(5): 538-545.

AOAC (1990) Official Methods of Analysis: Changes in Official Methods of Analysis Made at the Annual Meeting. Supplement (Vol. 15th edn). Washington, DC.: Association of Official Analytical Chemists.

AOCS (1989) Official methods and recommended practices of the American Oil Chemists'Society (Vol. 4th edn). Champaign: American Oil Chemists' Society.

Baldioli M, Servili M, Perretti G, Montedoro G (1996) Antioxidant activity of tocopherols and phenolic 
compounds of virgin olive oil. J. Am. Oil Chem. Soci. 73(11): 1589-1593.

Boselli E, Di Lecce G, Strabbioli R, Pieralisi G, Frega NG (2009) Are virgin olive oils obtained below $27^{\circ} \mathrm{C}$ better than those produced at higher temperatures? LWT-Food Sci. Technol. 42(3): 748-757.

Caponio F, Gomes T, Pasqualone A (2001) Phenolic compounds in virgin olive oils: influence of the degree of olive ripeness on organoleptic characteristics and shelf-life. Eur. Food Res. Technol. 212(3): 329-333.

Caponio F, Summo C, Paradiso VM, Pasqualone A (2014) Influence of decanter working parameters on the extra virgin olive oil quality. Eur. J. Lipid Sci. Technol. 116(12): 1626-1633.

Clodoveo ML (2012) Malaxation: Influence on virgin olive oil quality. Past, present and future-An overview. Trends Food Sci. Technol. 25(1): 13-23.

Clodoveo ML, Hbaieb RH, Kotti F, Mugnozza GS, Gargouri $M$ (2014) Mechanical strategies to increase nutritional and sensory quality of virgin olive oil by modulating the endogenous enzyme activities. Compr. Rev. Food Sci. Food Saf. 13(2): 135-154.

Criado M, Motilva M, Goni M, Romero M (2007) Comparative study of the effect of the maturation process of the olive fruit on the chlorophyll and carotenoid fractions of drupes and virgin oils from Arbequina and Farga cultivars. Food Chem. 100(2): 748-755.

Dag A, Kerem Z, Yogev N, Zipori I, Lavee S, Ben-David E (2011) Influence of time of harvest and maturity index on olive oil yield and quality. Sci. Hortic. 127(3): 358-366.

Dağdelen A, Tümen G, Özcan MM, Dündar E (2013) Phenolics profiles of olive fruits (Olea europaea L.) and oils from Ayvalık, Domat and Gemlik varieties at different ripening stages. Food Chem. 136(1): 41-45.

Di Giovacchino L, Solinas M, Miccoli M (1994) Effect of extraction systems on the quality of virgin olive oil. J. Am. Oil Chem. Soc. 71(11): 1189-1194.

Di Giovacchino L, Sestili S, Di Vincenzo D (2002) Influence of olive processing on virgin olive oil quality. Eur. J. Lipid Sci. Technol. 104(9-10): 587-601.

Gómez-Rico A, Salvador MD, La Greca M, Fregapane G (2006) Phenolic and volatile compounds of extra virgin olive oil (Olea europaea L. Cv. Cornicabra) with regard to fruit ripening and irrigation management. J. Agric. Food Chem. 54(19): 7130-7136.

Inarejos-García AM, Gómez-Rico A, Salvador MD, Fregapane G (2009) Influence of malaxation conditions on virgin olive oil yield, overall quality and composition. Eur. Food Res. Technol. 228(4): 671677.
ISO-5509 (1978) Animal and vegetable fats and oils preperation of methyl esters of fatty acids (ISO 5509) ISO-International Organization for Standardization (Vol. Method ISO 5509, 1-6). Geneve: International Organization for Standardization.

Jiménez B, Sánchez-Ortiz A, Rivas A (2014) Influence of the malaxation time and olive ripening stage on oil quality and phenolic compounds of virgin olive oils. Int. J. Food Sci. Technol. 49(11): 2521-2527.

Jimenez MA, Hermoso Fernandez M, Uceda Ojeda M (1995) Extraction of virgin olive oil by two-phase continuous system. Influence of different variables of the process on certain parameters related to oil quality. Grasas y Aceites 46: 299-303.

Kalua CM, Bedgood DR, Bishop AG, Prenzler PD (2006) Changes in volatile and phenolic compounds with malaxation time and temperature during virgin olive oil production. J. Agric. Food Chem. 54(20): 76417651.

Kelebek H, Kesen S, Selli S (2015) Comparative study of bioactive constituents in Turkish olive oils by LCESI/MS/MS. Int. J. Food Prop. 18(10): 2231-2245.

Konuskan DB, Mungan B (2016) Effects of variety, maturation and growing region on chemical properties, fatty acid and sterol compositions of virgin olive oils. J. Am. Oil Chem. Soc. 93(11): 14991508.

Kula Ö, Yıldırım A, Yorulmaz A, Duran M, Mutlu I, Kıvrak $M$ (2018) Effect of crushing temperature on virgin olive oil quality and composition. Grasas y Aceites 69(1): e239.

Lee SK, Mbwambo ZH, Chung H, Luyengi L, Gamez EJ, Mehta RG, Kinghorn AD, Pezzuto JM (1998) Evaluation of the antioxidant potential of natural products. Comb. Chem. High Throughput Screen. 1(1): 35-46.

Minguez-Mosquera M, Rejano-Navarro L, Gandul-Rojas B, Sanchez-Gomez AH, Garrido-Fernandez J (1991) Color-pigment correlation in virgin olive oil. J. Am. Oil Chem. Soc. 68(5): 332-336.

Paiva-Martins F, Santos V, Mangericão H, Gordon MH (2006) Effects of copper on the antioxidant activity of olive polyphenols in bulk oil and oil-in-water emulsions. J. Agric. Food Chem. 54(10): 3738-3743.

Polari JJ, Garcí-Aguirre D, Olmo-García L, CarrascoPancorbo A, Wang SC (2018) Interactions between hammer mill crushing variables and malaxation time during continuous olive oil extraction. Eur. J. Lipid Sci. Technol. 120(8): 1800097.

Preziuso SM, Di Serio MG, Biasone A, Vito R, Mucciarella MR, Di Giovacchino L (2010) Influence of olive 
crushing methods on the yields and oil characteristics. Eur. J. Lipid Sci. Technol. 112(12): 1345-1355.

Rizzo V, Torri L, Licciardello F, Piergiovanni L, Muratore G (2014) Quality changes of extra virgin olive oil packaged in coloured polyethylene terephthalate bottles stored under different lighting conditions. Packag. Technol. Sci. 27(6): 437-448.

Romani A, Lapucci C, Cantini C, leri F, Mulinacci N, Visioli $F$ (2007) Evolution of minor polar compounds and antioxidant capacity during storage of bottled extra virgin olive oil. J. Agric. Food Chem. 55(4): 1315-1320.

Romero MP, Tovar MJ, Ramo T, Motilva MJ (2003) Effect of crop season on the composition of virgin olive oil with protected designation of origin "Les Garrigues". J. Am. Oil Chem. Soc. 80(5): 423-430.

Seçmeler Ö, Güçlü Üstündağ Ö (2017) Behavior of lipophilic bioactives during olive oil processing. Eur. J. Lipid Sci. Technol. 119(9): 1600404.

Stefanoudaki E, Koutsaftakis A, Harwood JL (2011) Influence of malaxation conditions on characteristic qualities of olive oil. Food Chem. 127(4): 1481-1486.

Taticchi A, Esposto S, Veneziani G, Urbani S, Selvaggini R, Servili M (2013) The influence of the malaxation temperature on the activity of polyphenoloxidase and peroxidase and on the phenolic composition of virgin olive oil. Food Chem. 136(2): 975-983.
Velasco J, Dobarganes C (2002) Oxidative stability of virgin olive oil. Eur. J. Lipid Sci. Technol. 104(9-10): 661-676.

Welsh FW, Williams RE (1989) The use of vegetable oils to recover compounds from aqueous solutions. J. Chem. Technol. Biotechnol. 46(3): 169-178.

Yoo KM, Lee KW, Park JB, Lee HJ, Hwang IK (2004) Variation in major antioxidants and total antioxidant activity of Yuzu (Citrus junos Siebex Tanaka) during maturation and between cultivars. J. Agric. Food Chem. 52(19): 5907-5913.

Yorulmaz A, Poyrazoglu ES, Ozcan MM, Tekin A (2012) Phenolic profiles of Turkish olives and olive oils. Eur. J. Lipid Sci. Technol. 114(9): 1083-1093.

Yorulmaz A, Yıldırım A, Duran M, Kula Ö, Kıvrak M (2017) Impact of malaxation on quality and compositional characteristics of edremit yaglık olive oil. J. Food Process Preserv. 41(6): e13291.

Youssef O, Mokhtar G, Abdelly C, Mohamed SN, Mokhtar Z, Guido F (2013) Changes in volatile compounds and oil quality with malaxation time of Tunisian cultivars of Olea europea. J. Food Sci. Technol. 48(1): 74-81. 